\title{
Short Note: Cleistogamy in Eucalyptus tereticornis Sm. and its Genetic Implications
}

\author{
By V. K. Sharma, H. S. GinwaL* and A. K. Mandal \\ Division of Genetics and Tree Propagation, Forest Research Institute, P.O. I.P.E. Kaulagarh Road, \\ Dehradun 248195 (Uttaranchal) India
}

(Received $7^{\text {th }}$ December 2004)

\begin{abstract}
In a provenance cum progeny trial comprising 13 provenances and 91 families of Eucalyptus tereticornis Sm. of Australian and Papua New Guinean (PNG) origin, laid out in India in 2002, cleistogamy was found in a family emanating from CSIRO seed lot no. 13418, (tree no. DS000141) Sirinumu Sogeri Plat, PNG. This trait appears to be under genetic control, and presumably results in obligate selfing. This may lead to inbreeding depression in this family.
\end{abstract}

Key words: Eucalyptus tereticornis, cleistogamy, inbreeding depression, autogamy, self-pollination.

The genus Eucalyptus, that comprises about 700 species and varieties (ELDRIDGE et al., 1993), normally has chasmogamous flowers. It's species are generally considered to be largely cross-pollinated, and interspecific hybridization is quite frequent where spatial isolation barriers to inbreeding have either broken down or have been removed (PENFOLD and WILLIS, 1961; PRYOR, 1976; PотTs et al., 2003). However the frequency of selfing or out crossing is both genetically and environmentally conditioned (FRYXELL, 1957).

In the year 2002 a provenance cum progeny trial of Eucalyptus tereticornis comprising 13 provenances and 91 families of Australian and Papua New Guinea (PNG) origin and local control (Table 1) was established in the campus of Forest Research Institute, Dehradun, India $\left(30^{\circ} \mathrm{N}, 76^{\circ} \mathrm{E}, 610 \mathrm{~m}\right.$ altitude, mean annual rainfall 216 $\mathrm{cm})$. For carrying out inter- and intra-provenance crossing, phenological observations pertaining to flowering were taken in October 2004 for selection of parents.

In one family seed lot no. 13418 tree/Family DS 000141, cleistogamous flowers were observed (Fig 1a), while all 3000 other trees grown at the same site from 12 other provenances showed normal chasmogamous flowers. Since all 15 flowering plants belonging to this family spread over eight replicates showed cleistogamy, this trait appears to be genetically controlled.

In the cleistogamous flowers, the opercula showed an unusual tardiness in shedding. Although they separated from the floral receptacle as usual, the opercula were not shed and remained sitting on the style even after withering and turning brown in colour after fruit formation (Fig 1b). Such withered and dark brown opercula could be seen even after one month of fruit formation

\footnotetext{
*) Author for correspondence

(e-mail: ginwalhs@icfre.org; ginwalhs@rediffmail.com $)$
}

(Fig 1b). A close examination of such cleistogamous flowers at a relatively early stage, before their opercula turned brown revealed that many stamens and much pollen grains were sticking to the stigma, which were glistening with nector. Such a condition will presumably result in forced selfing because insects are unlikely to be able to contact anthers and stigma beneath the operculum (Fig. 1a). These observations are identical to those made by VENKATESH et al. (1973) on cleistogamous flowers of $E$. tereticornis. However, they differ from observations of cleistogamous flowers of a species of Eucalyptus in Tasmania whose opercula did not abscise from the receptacles (BARBER, 1954).

If cleistogamy and obligate selfing persist in the subsequent generations raised through seeds, this may lead to complete homozygosity in the population of this family and inbreeding depression. VENKATESH (1971) and VENKATESH et al. (1973) have shown that the mean number of seeds/capsule from cleistogamous flowers was considerably less than those developed from chasmogamous

Table 1. - Detail of geographical locations of E. tereticornis sources.

\begin{tabular}{|c|c|c|c|c|c|}
\hline \multirow{2}{*}{$\begin{array}{l}\text { Seed lot } \\
\text { No. }\end{array}$} & \multirow[t]{2}{*}{ Tree No. } & \multicolumn{4}{|c|}{ Origin } \\
\hline & & Locality & Lat. & $\begin{array}{l}\text { Long. } \\
\text { (0) }\end{array}$ & $\begin{array}{l}\text { Altitude } \\
\text { (m) }\end{array}$ \\
\hline 13399 & $\begin{array}{l}\text { JD945, JD946, JD948, JD949, } \\
\text { JD952, JD953 }\end{array}$ & $\begin{array}{l}\text { Oro bay to Emo, } \\
\text { PNG }\end{array}$ & 0857 & 14828 & 200 \\
\hline 13418 & DS000141 & $\begin{array}{l}\text { Sirinumu Sogeri } \\
\text { Plat, PNG }\end{array}$ & 0930 & 14726 & 580 \\
\hline 17762 & $\begin{array}{l}\text { MM1184, MM1 185, MM1186, } \\
\text { MM1 187 }\end{array}$ & Warwick, QLD & 2815 & 15205 & 450 \\
\hline 17768 & $\begin{array}{l}\text { MM1222, MM1223, MM1224, } \\
\text { MM1225, MM } 1226\end{array}$ & $\begin{array}{l}\text { Yurammie SF, } \\
\text { NSW }\end{array}$ & 3649 & 14945 & 170 \\
\hline 17770 & $\begin{array}{l}\text { MM1232, MM 1233, MM1234, } \\
\text { MM1235 }\end{array}$ & $\begin{array}{l}\text { Buckenbowra SF, } \\
\text { NSW }\end{array}$ & 3540 & $150 \quad 07$ & 110 \\
\hline 18732 & $\begin{array}{l}\text { DL590, DL591, DL592, DL } \\
\text { 593, DL594, DL596, DL597, } \\
\text { DL598, DL599, DL600 }\end{array}$ & $\begin{array}{l}\text { Selection flat } \\
\text { SF559, NSW }\end{array}$ & 2910 & 15258 & 40 \\
\hline 19315 & AS 11 to $\mathrm{AS} 21$ & Credition SF, QLD & 217 & 14831 & 730 \\
\hline 20468 & $\begin{array}{l}\text { PK76, PK77, PK 79, PK80, } \\
\text { PK81, PK82, PK83, PK84, } \\
\text { PK85 }\end{array}$ & Cardwell, QLD & 1810 & 14558 & 84 \\
\hline 20469 & PK53 to PK57 & $\begin{array}{l}\text { Mitchell River MT } \\
\text { Molloy, QLD }\end{array}$ & 1644 & $145 \quad 20$ & 390 \\
\hline 20470 & $\begin{array}{l}\text { JSL3228, JSL3230, JSL3232, } \\
\text { JSL3233, PK70, PK71, PK72, } \\
\text { PK73, PK74 }\end{array}$ & $\begin{array}{l}\text { Mill stream archer } \\
\text { creek, QLD }\end{array}$ & 1739 & 14521 & 670 \\
\hline 20471 & $\begin{array}{l}\text { AA473, AA475, AA476, } \\
\text { AA477, AA479, AA480, } \\
\text { AA485, AA490, AA491 }\end{array}$ & Helenvale, QLD & 1548 & 14515 & 325 \\
\hline 20472 & PK62 to PK68 & Walsh River, QLD & 1720 & 14518 & 762 \\
\hline 20474 & PK87 to PK97 & $\begin{array}{l}\text { Burdekin River, } \\
\text { QLD }\end{array}$ & 1948 & 14604 & 291 \\
\hline Local & $\begin{array}{l}\text { O.P seed collected from trees of } \\
\text { FRI-4, FRI-5 and Mysore gum } \\
\text { (E.tereticornis) }\end{array}$ & & 3030 & $76 \quad 04$ & 640 \\
\hline
\end{tabular}



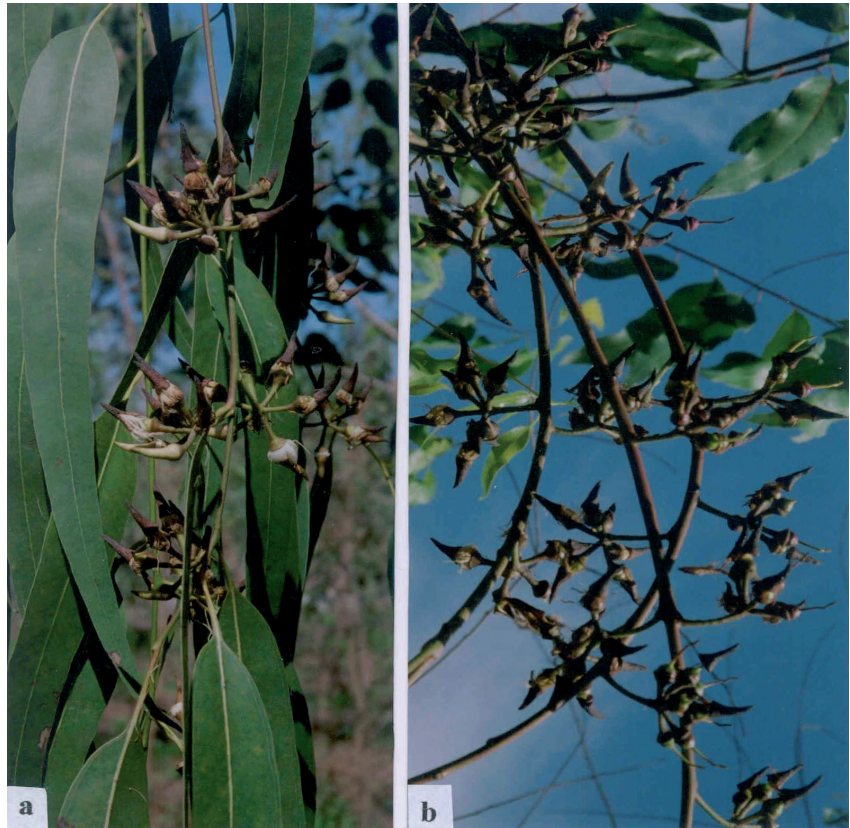

Figure 1. - (a) A portion of branch of E. tereticornis showing cleistogamous flowers. (b) Close up view of a branch showing development of fruits from cleistogamous flowers. Note that the opercula are still sitting on withered stigmas even after one month of fruit formation.

flowers. Our studies suggest that this cleistogamous family may also suffer inbreeding depression.

An assessment made for growth parameters viz. height and collar diameter of provenances/families at age 18 months revealed that this particular provenance/family performed poorly in relation to others. It ranked last but one in position with regard to height and diameter. For height and diameter, respectively it was 46.6 and $42.8 \%$ inferior to the best performing provenance/family and 18.9 and $24.5 \%$ inferior to the pooled means of the provenances. In general all 32 plants were poor in respect of growth performance. In addition, out of 32 plants, only 15 were found to initiate flowers at the age of 18 months.

\section{Acknowledgement}

The authors are grateful to Dr. Chris HaRwood, Australian Seed Centre, CSIRO, Canberra, Australia for providing seed lots of Eucalyptus tereticornis.

\section{References}

Barber, H. N. (1954): A sterile eucalypt. Papers and Proceedings of the Royal Society of Tasmania 88: 285-287.

EldRIDGe, K. G., J. Davidson, C. HaRwood and G. VAN WYK (1993): Eucalypts domestication and breeding. Oxford University Press, Oxford.

FRYXELL, P. A. (1957): Mode of reproduction of higher plants. Botanical Review 23: 135-233.

PENFold, A. R. and J. L. Willis (1961): The Eucalyptus Leonard Hill London and Inter Science Publication, New York.

Potts, B. M., R. C. Barbour, A. B. Hingston and R. E. VAILlancourt (2003): Turner Review No. 6 Genetic pollution of native eucalypt gene pools - identifying the risks. Australian Journal of Botany 51: 1-25.

PRYOR, L. D. (1976): The Biology of Eucalyptus, Edward Arnold, London.

VenKatesh, C. S. (1971): Cleistogamy in Eucalyptus tereticornis Sm. Paper presented at IUFRO working group meeting, Gainesville, Fla. USA, March, 14-20.

Venkatesh, C. S., R. S. ArYa and V. K. Sharma (1973): Natural selfing in planted Eucalyptus and its estimation. Journal Plantation Crops 1: 23-25.

\title{
Soil Temperature and Precipitation Affect the Rooting Ability of Dormant Hardwood Cuttings of Populus
}

\author{
By R. S. Zalesny JR. ${ }^{1, *)}$, R. B. Hall ${ }^{2)}$, E. O. BAueR ${ }^{1)}$, and D. E. RIemenschneideR ${ }^{1)}$
}

(Received 23 $3^{\text {rd }}$ December 2004)

\begin{abstract}
In addition to genetic control, responses to environmental stimuli affect the success of rooting. Our objectives were to: 1) assess the variation in rooting ability among 21 Populus clones grown under varying soil tem-

\footnotetext{
1) USDA Forest Service, North Central Research Station, Forestry Sciences Laboratory, 5985 Highway K, Rhinelander, WI 54501, U.S.A.

$\left.{ }^{2}\right)$ Iowa State University, Department of Natural Resource Ecology and Management, 339 Science II, Ames, IA 50011, U. S. A.

*) Corresponding author (research plant geneticist); Phone: (715) 362-1132; Fax: (715) 362-1166; E-mail: rzalesny@fs.fed.us
}

peratures and amounts of precipitation and 2) identify combinations of soil temperature and precipitation that promote rooting. The clones belonged to five genomic groups ([P. trichocarpa Torr. \& Gray $\times$ P. deltoides Bartr. ex Marsh] x P. deltoides 'BC'; $P$. deltoides 'D'; $P$. deltoides $\times P$. maximowiczii A. Henry 'DM'; $P$. deltoides $\times$ P. nigra L. 'DN'; $P$. nigra $\times$ P. maximowiczii 'NM'). Cuttings, 20 $\mathrm{cm}$ long, were planted in Iowa and Minnesota, USA, in randomized complete blocks at 1.2- x 2.4-m spacing across three planting dates during 2001 and 2002. Soil temperatures were converted to belowground growing degree days (GDD) (base temperature $=10^{\circ} \mathrm{C}$ ) accumulated over 14 days. Genomic groups responded similarly 